\section{Roma Ordusunda Beslenme Düzeni}

\author{
Diet of The Roman Army
}

\section{ÖZET}

Tarih boyunca ortaya çımış önemli devletlerin tamamı varlıklarını korumak ve sürdürebilmek için güçlü silahlı kuvvetlere ihtiyaç duymuşlardır. Bir ordunun savaşta ve barışta güçlü olmasını sağlayan pek çok etken söz konusudur. Komuta kademesinin becerisi, uygulanan taktikler, çağa ayak uydurabilme becerisi ve kullandıkları silah araç ve gereçleri bir ordunun güçlü olabilmesinin en önemli faktörleri asında yer almaktadır. Fakat tüm bu şartlar sağlanmış olsa bile sürdürülebilir bir lojistik olmadan başarısızlık kaçınılmaz olacaktır. Bu bağlamda Roma'da hem Cumhuriyet hem de İmparatorluk dönemlerinde askeri başarılar elde etmesinin temelinde sürdürülebilir bir lojistiğe sahip olması yatmaktadır. Eskiçağ tarihi içerisinde lojistikten kasıt ise askerler için gerekli yiyecek ve içeceğin temin edilmesidir. Roma da kurulduğu andan itibaren askerlerin bedensel ihtiyaçlarını gerçekleştirmek gayesi ile askerleri için gerekli her tür besin kaynağını düzenli bir şekilde sağlamıştır.

Anahtar Kelimeler: Vegetius, garum, canabae, lixae, panis militaris, buccelatum, laridum, acetum, tahıl (frumentum), panes militares castrenses, panes militares mundas, cibaria (tahıl harici besin), et, süt, peynir, kümes hayvanı.

\section{ABSTRACT}

All major powers which emerged through out the history needed strong and efficient military forces in order to preserve and prolong their existence. The strength of an army in peace and war depends on many different factors. For example skill of commanders, tactics employed, ability to keep forces modern, weapons and tools are among the most important factors that determinet be power of an army. However, without a sustainable logictical line, all these factors can not guarantee success. In this context, both in the Republican and Imperial periods the reason of Roman military successlies on having sustainable logistical lines. For the ancient history, the logictics meant provisions. Rome, beginning from its foundation, provided all necessary provision in order to fulfill the needs of its soldiers.

Keywords: Vegetius, garum, canabae, lixae, panis militaris, buccelatum, laridum, acetum, grain (frumentum), panes militares castrenses, panes militares mundas, cibaria, meat, milk, cheese, poultry.
Olcay TURAN

Yrd. Doç. Dr.

Kırklareli Üniversitesi,

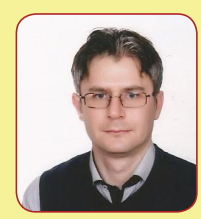

Fen-Edebiyat Fakültesi, Tarih Bölümü, e-mail: olcayayse@yahoo.com

«Akdeniz çevresinde ortaya çıkan tüm uygarlıklarda olduğu gibi Roma'da da temel besin maddesi buğdaydı. Buradan hareketle Roma askerlerinin diyetlerinde buğdayın başat bir rol üstlenmiş olduğunu söylemek yanlış olmaz.

Daha önce de ifade edildiği üzere Roma, askerlerin temel besin ihtiyaçlarını karşılama prensibi çerçevesinde düzenli olarak her bir askere günlük 830 gram buğday vermiştir »

Eser Geçmişi

10/09/2016'da başvuru alındı, 07/10/2016'da kabul edildi, 25 Aralık 2016' da yayınlandı.

Paper History

Received on 10/09/2016, Accepted on 07/10/2016, Published on 25 December 2016

DOİ:

http://dx.doi.org/10.21551/jhf.281938 


\section{Giriş}

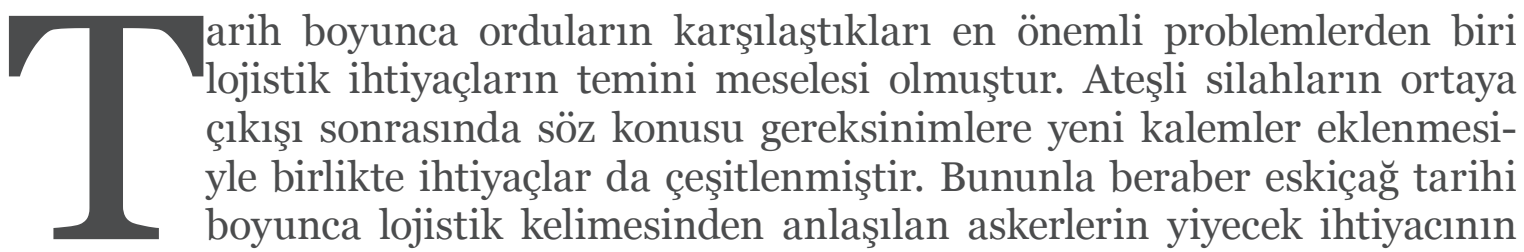
sağlanmasından ibaret olmuştur. Askerlerin gıda ihtiyacının karşılanması da generallerin ve yöneticilerin temel meselelerinden olmuş bu durum başarı sağlamanın şartlarından biri haline gelmiştir. Konu bu açıdan ele alındığında tarihteki en ünlü komutanlarından biri olan Napolyon Bonapart’nn söylemiş olduğu "ordular mideleri üzerinde yürür" sözü yalnızca kendi zamanı için geçerli değildir'. Zira orduların ilk olarak ortaya çıtıkları andan günümüze kadar geçen zaman diliminde gerçekleşen pek çok olay bu iddiayı doğrular mahiyettedir. Bu bağlamda tarihin ilk profesyonel gücü olan Roma ordusunun da ilgilenmesi gereken önemli problemlerden biri askerlerine yeterli gıda maddesini temin etmek olmuştur. Benzer şekilde Roma ordusunun beslenme düzeni hayati derecede önemli bir konu olup, bu çalışmada Roma askerlerinin hangi gıda maddelerini tükettiği konusu ele alınmaya çalışılacaktır.

Romalılar, ordunun güçlü olarak faaliyet yürütebilmesi için gereken temel ihtiyaçlardan birinin de etkili bir beslenme rejiminden geçtiğinin farkındaydılar. En önemli Roma askeri tarihçilerinden biri olan Vegetius da askerlerin beslenmesinin önemini belirtmiş ve lojistik sorunların halledilmediği durumlarda ordunun daha baştan savaşı kaybedeceğini iddia etmiştir². Antikçağ ordularında görev yapan askerler genellikle yiyeceklerini kendi imkânları ile sağlamışlardır. Bu duruma tezat olarak tarihin ilk profesyonel ordusu olan Roma ordusunun temel ihtiyaçları ise devlet tarafından karşılanmıştır ${ }^{3}$. Bununla beraber özellikle Almanya ve İngiltere'de bulunan askeri yerleşimlerde yapılan kazılar neticesinde buralarda bulunan birliklerin yerli halk tarafından üretilen besinleri tükettiğini göstermiştir ${ }^{4}$. Romalıların alışkın olduğu ve diyetlerinde önemli bir yere sahip olan şarap, zeytinyağı, baharatlara ek olarak "garum 5 " gibi soslar ise uzak mesafelerden gemiler vasıtasıyla askerlere ulaştırılmıştır. Askerler bu tür yiyecekleri kendi ceplerinden para ödemek suretiyle "canabae" olarak adlandırılan askeri kantinlerden almışlardır6. Sefer esnasında ise nakliye ve depolamada yaşanan zorluklar sebebiyle askerlerin yiyecek

1 David G. Chandler, The Campaigns of Napoleon: The Mind and Method of History's Greatest Soldier, Scribner Press, 2009, s. 856.

2 Flavius Vegetius Renatus, Epitoma Rei Militaris, çev. N. P. Milner, Liverpool University Press, 1995, 3.26.

3 Bununla beraber Livius'un da aktardığı gibi Roma'da belirtilen duruma tezat olaylar da meydana gelmiştir. Örneğin M.Ö. 216 tarihinde Livius, askerlere devlet tarafından yiyecek verilmediğini ifade etmiştir. Livius, Ab Urbe Condita, çev. B. O. Foster, Loeb Classical Library, London, 1957, 23. 21. 2.Polybios, Historion Prote, çev. W. R. Paton, Loeb Classical Library, London,1954, 6.39.13-15.

4 R. W. Davies, "The Roman Military Diet," Britannia, 2, 1971, s. 136.

5 Galya kökenli bir balık sosu olan garum Helen kolonistler vasıtasıyla Ege dünyasına oradan da Roma'ya aktarılmıştır. Garum balık iç organlarının tuz, karabiber, sirke, yağ ve şarap katılarak fermente edilmesiyle elde edilmekteydi. Maguelonne Toussaint-Samat, A History of Food, Wiley-Blackwell, 2009, s. 338.

6 Brian Campbell, The Roman Army, 31 BC- AD 337: A Sourcebook, Routledge, 1994, s. 141. 
çeşitleri ve bunların kalitesinde azalma olmaktaydı. Zorunlu olarak sefer esnasında askerlerin yiyecekleri garnizonlardakine oranla daha sıradan bir hale gelmekteydi. Her ne kadar Roma askerlerinin tükettikleri gıdaların çeşidi sefer esnasında azalsa da normal şartlarda orduyu takip eden "lixae" denen yiyecek satıcıları sayesinde besin çeşitliliği artmaktaydı ${ }^{7}$. Romalılar ezeli düşmanları olan Kartaca'yı ortadan kaldırmak gayesiyle kenti M.Ö. 146 tarihinde kuşatmışlardır. Bu esnada Romalı komutan Scipio Aemilianus, askerlerin sağlıklı bir şekilde beslenmesini temin etmek için yiyecek satıcılarına uyarıda bulunmuştur ${ }^{8}$.

\section{Roma Ordusunda Tahıl Tüketimi}

Akdeniz çevresinde ortaya çıkan tüm uygarlıklarda olduğu gibi Roma’da da temel besin maddesi buğdaydı. Buradan hareketle Roma askerlerinin diyetlerinde buğdayın başat bir rol üstlenmiş olduğunu söylemek yanlış olmaz. Daha önce de ifade edildiği üzere Roma, askerlerin temel besin ihtiyaçlarını karşılama prensibi çerçevesinde düzenli olarak her bir askere günlük 830 gram buğday vermiştir ${ }^{9}$. Askerler buğdaydan tuz ve zeytinyağ 1 kullanmak suretiyle buğday lapası ya da "panis militaris"10 adı verilen ekmek veya "buccelatum"11 olarak adlandırılan peksimet yapmaktaydılar. Tahıl istihkakına ek olarak çeşitli sebzeler ve meyveler ile baklagiller gibi gıdalardan oluşan 620 gram ağırlı̆̆ında ek besin de almaktaydılar. Tüm bunlara ek olarak "laridum" olarak adlandırılan 160 gram ağırlığında tütsülenmiş ette askerlere dağıtılmaktaydı. Katı gıdaların yanında içecek olarak ekşi şarap, "acetum" yani sirke ve şarap da devletin vermekle yükümlü olduğu kalemler arasındaydı. Bahsi geçen gıda ürünleri en az üç günde bir askerlere dağıtılmaktaydı ${ }^{12}$.

Daha öncede ifade edildiği üzere yazılı kaynakların aktardığı bilgiler ve askeri yerleşimlerde yapılan arkeolojik kazılar Roma ordusunun tahıl (frumentum) temelli beslenen bir ordu olduğunu ortaya çıkarmıştır. Belirtildiği üzere Roma ordusunda tahıl tüketim oranı diğer yiyecekler ile kıyaslandığında \% 60-75 mertebesindedir ${ }^{13}$. Tahıllar içerisinde de en fazla tercih edilen buğdaydı. Arpa ise acil durumlarda kullanılan bir besin maddesi olmasının yanında zaman zaman askerleri cezalandırmak gayesi ile de kullanılmıştır. Roma ve Kartaca arasında M.Ö. 218-202 yılları arasında gerçekleşen II. Pön savaşı esnasında kurallara aykırı hareket eden Roma askerlerine buğday yerine arpa verilmiştir ${ }^{14}$. Daha önceki örneklerde olduğu gibi ${ }^{15}$ M.Ö. 34 tarihinde Gaius Julius Caesar Octavianus'un askerleri Dalmaçya'daki Promona kuşatması esnasında korkaklık gös-

7 Jonathan Roth, Logistics of the Roman Army at War, Brill, 1999, s. 93-96.

8 Appianos, Appianos Romaika, çev. H. White, Loeb Classical Library, London, 1955, 17,116.

9 Peter Kehne, "War and Peacetime Logistics: Supplying Imperial Armies in the East and West", A Companion to the Roman Army, Blackwell, 2011, s. 324-325.

10 Carol A. Dery, "Food and Roman Army: Travel, Transport and Transmission”, Food on the Move, Prospect Books, 1997, s. 86.

11 Peter Kehne, a.g.m., s. 324.

12 Peter Kehne, a.g.m., s. 325.

13 Jonathan Roth, a.g.e., s. 18.

14 Livius 24.18, 27.13.9.

15 Caesar, Commentarii de Bello Civili (The Civil War), çev. Jane P. Gardner, Penguin Classics, 1976, 3.47.6; Cassius Dio, Historia Romana, çev. E. Car, Loeb Classical Library, London, 1961, 49.38.4. 
termesi üzerine birliğe decimasyon ${ }^{16}$ cezasına ek arpa ile beslenme cezası verilmiştir ${ }^{17}$. Tahıllardan çoğunlukla ekmek yapımında yararlanılmış ayrıca günümüzde de olduğu gibi çorba, yulaf lapası ya da çok çeşitli pastalar üretilmiştir ki Pompei’de bu durumu kanıtlayan örnekler ortaya çıkartılmıştır ${ }^{18}$. Yaşlı Plinius da panis militaris olarak adlandırılan kepekli asker ekmeğinden bahsetmiştir ${ }^{19}$. Romalılar iki tip ordu ekmeği tüketmişlerdir. Bunlardan ilki normal kalitede olandır ki buna "panes militares castrenses" denilmekteydi; diğeri ise yüksek kaliteli olup "panes militares mundas" denilmekteydi ve bu sonuncusu muhtemelen subaylar tarafından tüketilmiştir ${ }^{20}$. Askerler barış dönemlerinde doğal olarak taze ekmek tüketmişlerdir. Roma imparatorluk ordusunu ilk günlerine döndürmek isteyen İmparator Julianus, diğer rütbelerdeki askerler gibi yulaf lapası yemiştir²1.

\section{Roma Ordusunda Tahıl Haricinde Tüketilen Gıdalar}

Polybios gibi bazı antik çă̆ yazarları ve buradan hareketle Roma ordusunun beslenme tarzı konusunda fikir beyan eden bazı modern araştırmacılar Roma ordusunun tamamen tahıllara dayanan bir diyet uygulamış olduğunu iddia etmişlerdir. Bununla beraber günümüzde de olduğu gibi insan vücudunun sağlıklı bir şekilde varlığını sürdüre bilmesi için proteine ek olarak yeterli miktarda karbonhidrat, aminoasit, vitamin ve minerallere ihtiyaç duymaktadır. Bu bağlamda da tahıl haricindeki gıdaların tüketilmesi şarttır. Romalılar tahıllara ek olarak et, çeşitli sebze ve meyveler, çeşitli süt ürünleri, bakliyat, zeytinyağı, şeker, tuz ve şarap gibi besinleri de günlük diyetlerine eklemişlerdir ki bunların tamamını tanımlamak için Romalılar "cibaria" kelimesini kullanmışlardır. Plurharkhos ${ }^{22}$, Frontinus ${ }^{23}$, Appianos ${ }^{24}$ ve Cassius Dio ${ }^{25}$ gibi eski çă̆ yazarları Romalıların tahıl haricindeki gıdalarla da beslendiklerini eserlerinde aktarmışlardır. Cibaria kelimesi ile tanımlanmışolan yiyecek maddeleri laridum adı verilen tuzlanmış domuz, mercimek ya da fasulye (faba) gibi sebzeler, "caseus" yani peynir, sal (tuz) ve acetum olarak adlandırılan şaraptan oluşmaktadır. Bunlara ilaveten yemekleri pişirmek için zeytinyağından yararlanmışlardır.

16 Decimasyon, Latince'de “onuncunun öldürülmesi” anlamına gelmektedir. Savaş esnasında korkaklık gösteren^ lere ya da savaş alanından kaçanlara karşı uygulanan bir ceza türüdür. Söz konusu ceza için seçilen cohort'da yer alan askerler on kişilik gruplara ayrılır ve gruplar kendi içinde kura çekerler. Kurayı kaybedenler arkadaşları tarafindan taşlanarak veya sopayla öldürülürler. Kalan askerlere ise zahire istihkakı olarak buğday yerine arpa verilmekteydi. Konu ile ilgili olarak bkz. Livius, 2. 59. 9-11.

17 Appioanos, 5.26.

18 R. W. Davies, a.g.m., s. 125.

19 Plinius, Naturalis Historia, çev. H. R. Rackham, Loeb Classical Library, London, 1958, XVIII. 67.

20 R. W. Davies, a.g.m., s. 126.

21 Ammianus Marcellinus, Rerum Gestarum libri qui Supersunt, çev. J. C. Rolfe, Loeb Classical Library, London, 1963, 25. 2. 2 .

22 Plutharkhos, M. Licinius Crassus'un M.Ö. 53 tarihindeki Carrhae Savaşı sırasında ordunun Euphrates (Fırat) nehrini geçişi sonrasında askerlere mercimek ve tuz dağıttığını aktarmaktadır. Plutharkhos, Bioi Paralelloi: Crassus, çev. B. Perrin, Loeb Classical Library, London, 1948, 19. 5.

23 Frontinus ise Roma askerlerinin her tür gıdayı tükettiklerini iddia etmektedir. Frontinus, Strat, 2. 5.14.

24 Appianos, İspanya'da savaşan Roma legionlarının yalnızca buğday, arpa, şarap ve tuz almadan savaştıklarını ve bunun sonucunda da Roma askerlerinin sağlıklarının bozulduğunu belirtmiştir. Appianos, 9, 54.

25 Cassius Dio, Britanyalı Kraliçe Boudicca’nın ağzından aktardığı bilgide Roma askerlerinin ekmek, şarap ve zeytinyağı ile beslendiklerini iddia etmektedir. Cassius Dio, 62. 5. 5-6. 


\section{Et ve Hayvansal Gidalar}

Cibaria içerisinde yer alan en önemli kalemlerden birini et istihkakı oluşturmuştur. Bununla beraber Roma ordusunun yiyecek alışkanlıkları konusunda incelemelerde bulunan bazı araştırmacılar et tüketimi konusunda farklı görüşler bildirmişlerdir. Bu bağlamda kimi araştırmacılar Polybios gibi antikçağ yazarlarının iddialarına bel bağlamak suretiyle Roma ordusunun et tüketmediğini iddia etmişlerdir ${ }^{26}$. Gerçekte ise Davies gibi bazı araştırmacıların yaptığ fazla olduğu ortaya çıkmıştır ${ }^{27}$. Antikçağ yazarlarına ek olarak Roma askeri yerleşimlerinde yapılan kazılar neticesinde ortaya çıkartılan hayvan kemiklerinin incelenmesi sonucunda konu hakkındaki bilgilerimiz artmıştır. Özellikle Britanya ve Almanya'daki askeri yerleşimlerden yapılan araştırmalar sonucunda Romalıların en fazla sı̆̆ır eti yedikleri saptanmıştır. Romalılar eyaletlerden vergi olarak, satın alma, avlanma ya da "lustrati" olarak adlandırılan kurban törenleri sayesinde et elde etmişlerdir ${ }^{28}$. Roma ordusunda sığır eti tüketiminin yaygın olduğunu gösteren pek çok anlatım bulunmaktadır. Roma ordusunda köklü bir devrim gerçekleştiren Marius, M.Ö. 107 tarihinde Capsa'da bir miktar sı̆̆ır sürüsü ele geçirmiş ve bunları eşit olarak askerlerine dağıtmıştır ${ }^{29}$. Genç Cato ${ }^{30}$, Lucullus $^{31}$ ve Caesar $^{32}$ gibi ünlü komutanlara askerlerinin et ihtiyacını gidermek için sığır sürülerinden istifade etmiştir. Cassius Dio'nun aktarımına göre Marcus Aurelius, M.S. 170 tarihinde Germenleri yenilgiye uğratmış ve yapılan barış anlaşması şartları doğrultusunda sığır sürülerine el koymuştur ${ }^{33}$. Severuslar hanedanının kurucusu olan Septimius Severus, M.S. 197 yılındaki Parth seferi esnasında askerlerin et ihtiyacını karşılamak için sığır sürülerinden istifade etmiştir ${ }^{34}$.

Roma ordusunda sığır etine ek olarak domuz (porcus), koyun (oves) ve keçi (hircum) gibi hayvanların etleri de tüketilmiştir. Özellikle Romalılar domuz etini kullanarak laridum olarak adlandırılan beykın ya da domuz pastırması, "forciminia" yani sosis ve "perna" denilen jambon üretmişlerdir ${ }^{35}$. Polybios da Kuzey İtalya'daki orduların beslenmesinde domuzdan yararlanıldığını belirtmiştir ${ }^{36}$. Antik kaynaklara ek olarak Roma askeri yerleşimlerinde yapılan kazılarda sıklıkla sığır, domuz, koyun ve keçi kemiklerine

26 Hoverfield Roma ordusunun vejetaryen bir ordu olduğunu iddia etmiştir. F. Haverfield, "The Provisioning of Roman Forts", Tacitus, Agricola, Oxford University Press. 1922, s. 182.

27 R. W. Davies,a.g.m., s. 126.

28 Traianus Sütununda sığır, koyun ve domuzların kurban edildiğini gösteren pek çok resim söz konusudur. Konu ile ilgili olarak bkz. Jonathan Roth, a.g.e., s. 31. Brutus ve Cassius'da savaş öncesinde cohortlara kurban edilmesi için pek çok sığır dağıtmıştır. Ayrıca Romalılar elde ettikleri zaferler sonrasında kutlamalar için de kurbanlar düzenlemişlerdir. Bkz. Plutharkhos, Brutus, 39. 1. Josephus, M.S. 70 tarihinde Kudüs'ün ele geçirilmesi sonrasında Titus'un kurban edilmesi için askerlere pek çok sığır verdiğini belirtmiştir. Bkz. Josephus, Bellum Judaicum (The Jewish War), çev. G. A. Williamson, Penguin Classics, 1984, 7. 16.

29 Sallust, The Jugurthine War/The Conspiracy of Catiline, çev. S. A. Handford, Penguin Classics, $1964,90$. $2 ; 91.1$.

30 Plutarkhos. Cato, 56. 3.

31 Appianos, 9. 54.

32 Caesar, Commentarii de Bello Gallico (The Gallic War), çev. H. J. Edwards, Loeb Classical Library, 1917, 5.21.6, 6.3.2, 6. 1; Caesar, Commentarii de Bello Civili,1.48.

33 Cassius Dio, 72.11.2.

34 Vegetius, 3.9.103.

35 Jonathan Roth,a.g.e., s. 26.

36 Polybios, 2.15.2-3. 
rastlanmıştır. Kemikler üzerindeki incelemeler neticesinde hayvanların olgunluk yaşına gelmeden kesildikleri saptanmıştır. Buna ek olarak kemiklerin büyük bir kısmının kırık olduğu belirlenmiştir. Bu durumun temel nedeni ise Romalıların kemik iliğini kullanarak çorba yapmış olmalarıdır ${ }^{37}$.

Romalılar hayvanları süt (lactis) ya da peynir (caseus) gibi hayvansal gıdaları temin etmek gayesi ile de beslemişlerdir ${ }^{38}$. Roma askeri yerleşimlerinde yapılan kazılarda peynir elde etmek amacıyla kullanılmış pek çok malzeme ortaya çıkartılmıştır ki bu da bize askerlerin kendi peynirlerini kendilerinin yapmış olduğunu göstermektedir ${ }^{39}$. Özellikle sefer esnasında besin değerinin yüksek ve ağırlığının az olmasından ötürü peynir askerler tarafından tercih edilen bir gıda olmuştur. Muhtemelen her bir Roma askeri günlük olarak bir "uncia" ya da 27 gram peynir tüketmiştir40.

Romalılar evcil hayvanlara ek olarak avlanmak suretiyle yabani hayvan eti de tüketmişlerdir. Waddon Hill'deki Claudian dönemine ait bir kalede çok sayıda tavşan kemiği ortaya çıkartılmıştır ${ }^{41}$. Frontinus, Lucullus'un İspanya'daki birliklerinin geyik ve tavşan gibi av hayvanlarının etlerini yediklerini belirtmiştir. Yine acil durumlarda Romalılar yük hayvanları ve atları da tüketmişlerdir ${ }^{42}$.

Roma askeri yerleşimlerinde yapılan kazılarda askerlerin deniz ürünlerinden istifade ettikleri belirlenmiștir. Bu bağlamda Butzback'da turnabalığı, Chester'da levrek, Saalburg'da mersin balığı ve Hood Hill'de ise morina balığının tüketilmiş olduğunu gösteren kalıntılara rastlanmıştır. Bunlara ek olarak Brecan, Caerlean ve Carbridge'de tanımlanamamış balık türleri ortaya çıkartılmıştır. Vindonissa'da da balık kılçıklarına ek olarak bir olta bulunmuştur ki askerler muhtemelen Aare nehrinden balık tutmuşlardır. Yine burada ortaya çıkartılmış olan bir yazıtta askerlerin ton balığı tükettikleri yazılıdır. Richboraugh'da da balık tutmak amacıyla kullanılan araçlar ortaya çıkartılmıştır. Waddon Hill'de morina kılçıkları bulunmuştur. Ren nehri ağzında bulunan Walkenburg'daki auxiliary kalesinde mersinbalığı ve turnabalığının da dâhil olduğu çok sayıda balık türüne ait kalıntılar ortaya çıkartılmıştır. Adı geçen yerleşimde ayrıca domuz balığı, balina, mürekkep balığı gibi türler saptanmıştır ${ }^{43}$. Tüm bunlara ek olarak M.S. II. yüzyıl başlarına ait bir papirüste Terentianus adındaki bir legioner Aleksandreia'daki babasına yazmış olduğu mektupta balıktan zehirlendiği için gelemediğini belirtmiştir ${ }^{44}$. Balıklara ek olarak deniz kabuklularına ait kalıntılarda gün yüzüne çıkartılmıştır. Özellikle Maryport ve South Shields gibi askeri yerleşimlerde istiridye, midye, deniz minaresi ve deniz salyangozuna rastlanmıştır ${ }^{45}$. Bu yerleşimlere ek olarak denize oldukça uzak mesafede yer alan Vindonissa'da deniz kabuklularına ait kalıntılar saptanmıştır. Burada bulunan kalıntıların

37 Appianos,85; ayrıca bkz. R. W. Davies, “The Roman Military Diet”, Britannia, vol. 2, 1971, s. 126-127.

38 Plinius eserinde Romalıların inek, koyun ve keçi sütü kullanarak peynir ürettiklerini belirtmiş̧ir. Plinius, Naturalis Historia, 11.237-242.

39 R. W. Davies, a.g.m., s. 127-128.

40 Jonathan Roth, a.g.e., s. 34.

41 R. W. Davies, a.g.m., s. 128.

42 Appianos, 9. 54.

43 R. W. Davies, a.g.m., s. 129-130.

44 Joan P. Alcock, Food in the Ancient World, Greenwood Press, 2006, s. 236.

45 Joan P. Alcock, "Pisces in Britannia. The Eating and Portrayal of Fish in Roman Britain", Fish: Food from the Waters, ed. Harlan Walker, Prospect Books, 1998, s. 28. 
analizi sonucunda bu canlıların Portekiz ve İngiliz Kanalı’ndan getirilmiş olduğunu görülmektedir ${ }^{46}$.

Roma ordusunda kümes hayvanları düzenli diyetin bir parçasıydı. Vegetius, kuşatma esnasında kümes hayvanlarının öldürülmemesi gerektiğini zira bu hayvanların kolaylıkla ve ucuz bir şekilde beslenmesinin mümkün olduğunu belirtmiştir ${ }^{47}$. Roma askeri yerleşimlerinde yapılan kazılar neticesinde yaygın bir şekilde tavuk, ördek ve kaz kalıntılarına rastlanmıştır ${ }^{48}$. Buna ek bazı askeri yerleşimlerde ise av kuşlarına ait kalıntılar ortaya çıkartılmıştır. Almanya'da bulunan auxiliary askerlerinin komutanları onları sık sık kaz avına göndermiştir ${ }^{49}$. Kümes hayvanları yumurta elde etmek için de beslenmiş olup, Roma askeri yerleşimlerinde yapılan kazılarda yumurta kabuklarına rastlanmıştır ${ }^{50}$.

\section{Sebzeler ve Meyveler}

Roma askerleri hayvansal gıdalar yanında ağırlıklı olarak sebze ve meyve de tüketmişlerdir. Bununla beraber sebzelerin sıradan yiyecekler olmasından ötürü kaynaklarda fazlaca zikredilmemiștir. Antikçağ kaynakları ve Roma askeri yerleşimlerinde yapılan kazılar bağlamında askerlerin özellikle "lentes" (mercimek), fabae (fasulye) ve "fisa" (bezelye) gibi baklagilleri tüketmiş oldukları belirlenmiştir ${ }^{51}$. Olağanüstü durumlarda Romalılar daha az hoşa giden çalı, kök, çimen ya da meşe palamudu tarzında bitkileri de tüketmek zorunda kalmışlardır52. Yapılan araştırmalar bağlamında Roma ordusunda "poma" olarak adlandırılan meyvelerin de tüketilmiş olduğu saptanmıştır. Vegetius da meyvelerin önemini belirterek, bir kuşatma öncesinde tahıl ve diğer besin maddeleri ile beraber meyvelerin de depolanmak suretiyle kuşatmaya hazırlanılmasını tavsiye etmekte$\operatorname{dir}^{53}$. Özellikle Roma askeri yerleşimlerinde yapılan kazılarda farklı türde meyve kalıntıları ortaya çıkartılmıştır. Bu bağlamda Vindonissa'da yapılan çalışmalar neticesinde buradaki Roma askerlerinin elma, armut, erik, kiraz, şeftali, üzüm ve dut gibi meyveler tükettiklerini; bunlara ek olarak kestane, ceviz ve findık yedikleri saptanmıştır ${ }^{4}$. İmparator Hadrianus döneminde Saalburg'da üstlenmiş olan II. Raetorum chorsuna bağlı askerlerin bu bölgede yetişen erik, mürdüm eriği, yabani kiraz, şeftali, fındık ve ceviz yedikleri belirlenmiştir ${ }^{55}$. Masada'da ise askerler tarafından tüketilen zeytin, nar, üzüm, hurma, erik ve kayısı kalıntılarına rastlanmıştır ${ }^{5}$.

46 Duncan B. Campbell, Roman Legionary Fortresses 27 BC-AD 378, Osprey Publishing, 2006, s. 45.

47 Vegetius, IV. 7. Ayrica Bkz. R. W. Davis, a.g.m., s. 131.

48 R. W. Davies, a.g.m., s. 130.

49 Plinius, Naturalis Historia, X. 54.

50 Karen R. Dixonand Pat Southern, The Roman Cavalry, Routledge, 1992, s. 93.

51 Neuss'dakilegion kampında yapılan kazılarda ortaya çıkartılan bitkiler analiz edildiğinde \% 53.1'inin baklaa giller olduğu görülürken, Plutharkhos'da mercimeğin Roma askerleri tarafindan tüketildiğini ifade etmiştir. Marcus Junkelmann, Panis Militaris, Verlag Philip von Zabern, 1997, s. 137. Plutarkhos. Crassus, 19. 5.

52 Tacitus, The Hisories, çev. Rhiannon Ash, Penguin Classics, 2009, 4.60. Appianos, 1.6,50.

53 Vegetius, 4.7. Ayrica bkz. Jonathan Roth,a.g.e., s. 42.

54 R. W. Davis, a.g.m., s. 133.

55 J. S. Wacher, The Roman World, Routledge, 1987, s. 159.

56 David S. Potter, A Companion to the Roman Empire, Wiley-Blackwell, 2010, s. 92. 


\section{Zeytinyağı}

Bir Akdeniz toplumu olan Romalılar arasında zeytinyağı kullanımı oldukça yaygındı. $\mathrm{Bu}$ durumun bir yansıması olarak ordu içerisinde de zeytinyağı tercih edilen bir gıdaydı. Zeytinyağı yemek pişirme yanında, temizlik ve aydınlanma amacıyla da kullanılmıştır. Romalılar tarafından "oleum” olarak adlandırılan zeytinyağının ordudaki kullanımı konusunda pek çok kaynak bulunmaktadır. Örneğin Cassius Dio, M.S. 61 tarihinde Britanya'da ortaya çıkan isyanın lideri olan Baudicca'nın ağzından Roma askerlerinin ekmek, şarap ve zeytinyağı ile beslendiklerini aktarmıştır ${ }^{57}$. Romalılar zeytinyağından temelde besin olarak yararlandıkları gibi ayrıca tıbbi amaçlarla da kullanmışlardır. Örneğin Mısır'da ortaya çıkartılan bir papirüste "valetudinarium" (hastane) da yatan askerlere zeytinyağı verilmesi tavsiye edilmektedir ${ }^{8}$. Yapılan çalışmalar ışı̆̆ında bir Roma askerinin günde 4.4 santilitre zeytinyağı tükettiği belirlenmiştir ${ }^{59}$.

\section{Tuz}

Romalılar belirtilen gıdalara ek olarak vücudun temel ihtiyaçlarından biri olan tuzu askerleri için temin etmişlerdir. Her ne kadar günümüzde tuzun bünye için gerekli bir mineral olduğu saptanmışsa da antikçağlarda yaşayan insanlar bu bilgiden yoksunlardı. Bu sebeple tuz etin korunması, yemeklerin tatlandırılması ve tıbbi amaçlarla kullanılmaktaydı. Roma ordusundaki tuz kullanımı konusunda Vegetius ${ }^{60}$ ve Appianos ${ }^{61}$ gibi pek çok dönem yazarı bilgi vermiştir. Bunlara ek olarak Caesar ve Crassus da askerlerine tuz tayını sağlamışlardır ${ }^{62}$.

\section{Çeşitli Sıvılar}

Tüm canlılar da olduğu gibi insan için temel ihtiyaçlardan biri de sudur. İnsan her hangi bir yiyecek tüketmeden haftalarca hayatta kalabilirken, susuz ancak birkaç gün hayatta kalabilir. Özellikle askerler zorlu koşullarda çok fazla efor sarf etmeleri bağlamında suya daha fazla ihtiyaç duyarlar. Buradan yola çıkarak Roma askerleri içinde suyun en temel ihtiyaç olduğu söylenebilir. Roma ordusu konusunda bilgi veren dönem kaynakları askerlerin tükettikleri su miktarı ya da lojistik manada suyun nasıl temin edildiği konusunda bilgi sağlamaktadır. Kaynakların da vermiş olduğu bilgiler ışığında Roma ve müttefik askerlerinin sudan eşit miktarda yararlandıkları söylenebilir ${ }^{63}$. Roma ordusunda su ikmalinden "metatores" olarak adlandırılan görevliler sorumluydu. Bu askerlerin temel görevi sefer esnasında su kaynaklarını tespit etmek ve buna göre ordunun yürüyüş rotasını belirlemekti ${ }^{64}$. Yetenekli komutanlar özellikle sefer esnasında orduya su tedarik etmek için azami gayret sarf etmişlerdir ${ }^{65}$.

57 Cassius Dio, 62.2.5.

58 Jonathan Roth, a.g.e., s. 35.

59 Jonathan Roth, a.g.e., s. 35.

60 Vegetius, 3. 3.

61 Appianos, 9,54; 4,17;

62 Caesar, Commentarii de Bello Civili, 2.37.5; Plutarkhos, Crassus, 19. 5.

63 Polybios, 6. 39. 9.

64 Yann Le Bohec, TheImperial Roman Army, Routledge, 1989, s. 46.

65 Konu ile ilgili olarak bkz. Plutarkhos, Sulla,16. 1; Caesar, Commentarii de Bello Gallico,4.11.4; Commentarii de Bello Civili, 3.66.6. 
Romalılar suya ek olarak hem besin hem de sıvı ihtiyacını karşılamak ve bunlardan daha önemlisi hoşlandıkları için bol miktarda şarap tüketmişlerdir. Lucullus'un M.Ö. 153 yılındaki İspanya seferi sırasında kullanmış olduğu lojistik malzemeler ile ilgili ele geçen bilgiler arasında eski şarap ya da "oinos" ve "oxos" ekşi şarap kelimeleri de yer almaktadır" Roma'da şarap tüketimi konusunda yapılan çalışmalarda alt sınıfların çoğunlukla "posca” olarak adlandırılan ekşi şarabı sulandırarak tükettikleri belirtilmiş olup, antik kaynaklarda bu iddiayı doğrulamaktadır ${ }^{67}$. Kesin olmamakla birlikte Roma askerlerinin tıpkı alt sınıflar gibi poscayı tüketmiş oldukları ileri sürülmektedir. Zaman zaman Roma askerleri kaliteli şarap tüketmişlerse de bu durum genellikle disiplinsizlik olarak algılanmıştır. Konu ile ilgili olarak antik kaynaklarda bazı bilgiler yer almaktadır. Örneğin Sallustius disiplinli generallerin eski şarap ithalini yasakladıklarını ifade etmiştir ${ }^{68}$. Muhafazakârlığıyla ünlenmiş olan Yaşlı Cato ise genellikle "vinum" şarabını tercih etmiştir"69. M.S. 193-94 tarihleri arasında Septimius Severus'un en büyük siyasi rakibi olan Pescennius Niger ise askerlerine yalnızca ekşi şarap içmelerini emretmiştir ${ }^{70}$.

Roma'nın egemenliğinde bulunan topraklardan askere alınan auxiliary birlikleri yerel alışkanlıklarını devam ettirmişlerdir. Özellikle kuzey sınırından gelen askerler şarap yerine alışkın oldukları bira gibi geleneksel içkileri kullanmışlardır. Bununla beraber bu askerler zaman içerisinde Roma geleneklerine ve doğal olarak da şarap içmeye alışmışlardır $^{71}$. Appianos, Caesar'ın ordusundaki Germenlerin şarap içtiklerinden bahsetmektedir $^{72}$. Tüm bunlara ek olarak özellikle kuzey sınırında görev yapan Roma askerleri yerli geleneklere zaman içerisinde uyum sağlamışlar ve bu bağlamda da şaraba ek olarak bira içmişlerdir. Roma askeri yerleşimlerinde yapılan kazılarda ortaya çıkartılan amphoralar sayesinde Romalıların askerlerinin ihtiyacını karşılamak amacıyla geniş oranda bir ticaret ağı oluşturdukları gözlemlenmektedir. Örneğin M.S. I. yüzyıla tarihlendirilen Vindonissa'daki legion kalesinde ortaya çıkartılan amphoraların Güney İtalya'daki Surrentum ve Sicilya'daki Messina’dan geldiği belirlenmiştir ${ }^{73}$.

Roma askerlerinin yeme içme alışkanlıkları askeri yerleşimlerde ortaya çıkartılan grafitiler ve "titulipicti" olarak adlandırılan amforalar üzerindeki etiketlerden de anlaşılmaktadır. Bu konudaki en iyi buluntular M.S. I. yüzyıla ait Vindonissa'da ortaya çıkartılmıştır. Yine Romalılar tarafından yiyecekleri tatlandırmak gayesi ile kullanılmış olan bal da amforalar üzerinde yazılıdır ${ }^{74}$. Üst sınıflarda yer alan Romalılar garum gibi pahalı sosları tüketirlerken, askerler ise daha ucuz olan "muria"yı tüketmişlerdir"5.

66 Andrew Dalby, Food in the Ancient World from A to Z, Routledge, 2003, s. 270.

67 Plautus, The Braggart Soldier, çev. Wolfgang de Melo, Loeb Classical Library, 2011, 3.2.837

68 Sallutius, 44.5

69 Plinius, Naturalis Historia,III. 15; Livius, 37.33 .2

70 Historia Augusta, Pescennius Niger, Vol. II, çev. David Magie, Loeb Classical Library, 1924, 10. 3

71 Jonathan Roth, a.g.e., s. 40.

72 Appianos, 2.10,64; Tacitus, Agricola and Germania, çev. James Rives, Penguin Clasiccs, $2010,23$.

73 R. W. Davies, a.g.m., s. 132.

74 R. W. Davies, a.g.m., s. 131.

75 Malcolm Todd, A Companion to Roman Britain, Blackwell Publishing, 2004, s. 372. 


\section{SONUÇ}

Antik Batı özellikle de Roma dönemi ile ilgili tarihi kaynaklara dayanarak fikir beyan eden bazı araştırmacılar, Roma ordusunun tahıl temeli bir beslenme rejimine sahip olduğunu ileri sürmüsslerdir. Bununla beraber Roma askeri yerleşimlerinde yapılan kazılar neticesinde ortaya çıkartılan buluntular bu iddiaları geçersiz kılmıştır. Gerçekte Roma ordusunun diyetinde ağırlıklı olarak tahıllar yer almışsa da kırmızı ve beyaz et çeşitleri, çeşitli baklagiller, sebzeler, meyveler, şarap ve bira türlerinin de tüketilmiş olduğu anlaşılmıştır.

İnsan vücudunun günlük aktivitelerini gerçekleştirebilmesi için 2000-1600 arasında kaloriye ihtiyacı vardır. Belirtilen kalori miktarına ek olarak vücudun ihtiyaç duyduğu çeşitli proteinler, karbonhidratlar, vitaminler, mineraller, yağ ve sıvıların da dengeli bir şekilde tüketilmesi gerekmektedir. Sıradan bir yetişkin için bu durum söz konusuyken, askerlik gibi yüksek enerji gerektiren bir işle meşgul olan kişilerin doğal olarak hem daha fazla kaloriye hem de dengeli bir şekilde beslenmeye ihtiyaç duyması kaçınılmazdır. Roma yöneticileri başlangıçtan itibaren bu durumun farkına varmışlar ve Roma emperyalizminin en önemli güç unsuru olan, ordunun etkinliğini arttırmak gayesiyle askerlerin dengeli ve düzenli bir şekilde beslenebilmeleri için her tür önlemi almışlardır. Bu çabalarla bağlantılı olarak askeri yerleşimlerde ortaya çıkan buluntuların da gösterdiği gibi ticaret vasıtasıyla pek çok ürün farklı bölgelere nakledilmiş ve bu durum dönem ticaretine pozitif katkı sağlamıştır. Sonuçta Roma ordusunun dönemin en önemli askeri gücü haline gelerek, giriştiği mücadelelerde üstün başarılar elde etmesinin ardında yatan temel nedenlerden biri de hiç kuşkusuz askerlerin dengeli ve düzenli bir yiyecek istihkakına sahip olmasıdır.

\section{KAYNAKÇA}

Alcock, Joan P., "Pisces in Britannia. The Eating and Portrayal of Fish in Roman Britain”, Fish: Food from the Waters, ed. Harlan Walker, Prospect Books, 1998, 20-36.

Alcock, Joan P., Food in the Ancient World, Greenwood Press, 2006.

Ammianus Marcellinus, Rerum Gestarum libriqui Supersunt, çev. J. C. Rolfe, Loeb Classical Library, London, 1963.

Appianos, Appianos Romaika, çev. H. White, Loeb Classical Library, London, 1955.

Caesar, Commentarii de Bello Civili (The Civil War), çev. Jane P. Gardner, Penguin Classics, 1976.

Caesar, Commentarii de Bello Gallico (The Gallic War), çev. H. J. Edwards, Loeb Classical Library, 1917.

Campbell, Brian., The Roman Army, 31 BC- AD 337: A Sourcebook, Routledge, 1994 . 
Campbell, Duncan B., Roman Legionary Fortresses 27 BC-AD 378, Osprey Publishing, 2006.

Cassius Dio, Historia Romana, çev. E. Car, Loeb Classical Library, London,1961.

Chandler, David G., The Campaigns of Napoleon: The Mindand Method of History's Greatest Soldier, Scribner Press, 2009.

Dalby, Andrew., Food in the Ancient World from A to Z, Routledge, 2003.

Davies, R. W., “The Roman Military Diet,” Britannia, 2, 1971, 122-142.

Dery, Carol A., "Food and Roman Army: Travel, Transport and Transmission", Food on the Move, Prospect Books, 1997, 84-96.

Flavius Vegetius Renatus, Epitoma Rei Militaris, çev. N. P. Milner, Liverpool Unie versity Press, 1995.

Haverfield, F., “The Provisioning of Roman Forts”, Tacitus, Agricola, Oxford University Press. 1922.

Historia Augusta, Pescennius Niger, Vol. II, çev. David Magie, Loeb Classical Library, 1924.

Josephus, Bellum Judaicum (The Jewish War), çev. G. A. Williamson, Penguin Classics, 1984.

Junkelmann, Marcus, Panis Militaris, Verlag Philip von Zabern, 1997.

Karen R. Dixonand Pat Southern, The Roman Cavalry, Routledge, 1992.

Kehne, Peter., "War and Peacetime Logistics: Supplying Imperial Armies in the East and West”, A Companion to the Roman Army, Blackwell, 2011, 323-338.

Le Bohec, Yann., The Imperial Roman Army, Routledge, 1989.

Livius, Ab Urbe Condita, çev. B. O. Foster, Loeb Classical Library, London, 1957.

Plautus, The Braggart Soldier, çev. Wolfgang de Melo, Loeb Classical Library, 2011.

Plinius, Naturalis Historia, çev. H. R. Rackham, Loeb Classical Library, London, 1958.

Plutharkhos, Bioi Paralelloi: Crassus, çev. B. Perrin, Loeb Classical Library, London, 1948. 
Polybios, Historion Prote, çev. W. R. Paton, Loeb Classical Library, London,1954.

Potter, David S., A Companion to the Roman Empire, Wiley-Blackwell, 2010.

Roth, Jonathan., Logistics of the Roman Army at War, Brill, 1999.

Sallust, The Jugurthine War/The Conspiracy of Catiline, çev. S. A. Handford, Penguin Classics, 1964.

Tacitus, Agricola and Germania, çev. James Rives, Penguin Clasiccs, 2010.

Tacitus, The Hisories, çev. Rhiannon Ash, Penguin Classics, 2009.

Todd, Malcolm., A Companion to Roman Britain, Blackwell Publishing, 2004

Toussaint-Samat, Maguelonne ., A History of Food, Wiley-Blackwell, 2009.

Wacher, J. S., The Roman World, Routledge, 1987. 